\title{
Ganti Nama di Kalangan Keturunan Tionghoa Peraturan dan Kebebasan
}

\author{
Irzanti Sutanto
}

\begin{abstract}
In 1966 New Order regime imposed a regulation that demands Indonesian citizens of Chinese descendants to change their name with "Indonesian name" to accelerate the process of assimilating "foreign descendents" into Indonesian society. This article examines this practice of changing names by surveying the name of Chinese in the obituary section of mass media. The writer argues that the regulation allows the Chinese descendants to change their names in any way they find appropriate. In doing so, it expands the anthrophoneme deixis function in
Indonesia.
\end{abstract}

Kata Kunci Peraturan pemerintah, antrofonem, warga negara, komunitas Tionghoa.

Benarkah pernyataan William Shakespeare yang berbunyi What is in a name? Dalam artikel ini, name yang dikaji adalah nama orang. Pernyataan tesebut dapat disetujui atau tidak disetujui. Mungkin benar, siapa pun nama presiden pertama Republik Indonesia, sosoknya tetap sosok "Soekarno." Namun, ditinjau dari pemberian nama, pada umumnya, pemilihan nama tidak dilakukan sembarang. Misalnya, seseorang diberi nama Sugiharto dengan harapan kelak ia kaya raya sesuai dengan makna namanya. Apa pun alasannya, pemilihan sebuah nama pasti tidak sembarang. Demikian pula halnya dengan penggantian nama. Cukup banyak artis mengganti atau diminta mengganti namanya agar sesuai dengan dunia komersial, seperti Roy Wicaksono menjadi Roy Martin, Cucu Suryaningsih menjadi Evie Tamala, Marjolein Tambayong menjadi Rima Melati, Sudarwati menjadi Titik Puspa, Wahyu Setyaning Budi menjadi Yuni Shara (Sotyati 2002: 1). Dalam hal ini bukan makna nama yang menjadi pertimbangan utama, melainkan wujud fisik nama tersebut. Selain alasan komersial, ada pula alasan ketidakcocokan antara nama dan penyandangnya yang menimbulkan hal-hal buruk. Karena itu nama orang tersebut diganti.

Berbeda dengan alasan-alasan tersebut, pada 1966, keturunan Tionghoa berkewarganegaraan Indonesia dikejutkan oleh keputusan pemerintah No. 127/U/Kep/12/1966 yang dikeluarkan oleh Ketua Presidium Kabinet 
(lihat Lampiran). Tidak asing lagi, peraturan tersebut mengenai penggantian nama Tionghoa yang terdiri dari tiga suku terpisah menjadi nama bercirikan Indonesia. Pada surat keputusan itu, ada dua hal yang berkenaan langsung dengan pokok bahasan tulisan ini, yaitu Bab I Pasal 1 ayat 1 dan 2. Peraturan itu ditaati hampir oleh semua WNI keturunan Tionghoa, tetapi ada yang tetap mempertahankan nama Tionghoanya, misalnya Kwik Kian Gie dan Yap Thiam Hien, dua orang yang cukup dikenal di Indonesia. Keputusan Presidium Kabinet tersebut tidak memuat sanksi apabila seorang WNI keturunan Tionghoa tidak menaati peraturan itu. Oleh karena itu, peraturan tersebut dapat dianggap sebagai suatu imbauan berdasarkan ketiga butir yang tercantum pada bagian Menimbang.

Tulisan ini mengkaji keleluasaan pemilihan nama Indonesia (selanjutnya disingkat NI) sebagai pengganti nama Tionghoa (selanjutnya disingkat NT). Data yang berjumlah 810 pasang nama (NT dan NI) diambil dari berita duka dalam harian Suara Pembaruan tahun 2001. Pada berita duka tersebut masih cukup banyak orang Tionghoa yang mencantumkan NT-nya, terutama mereka yang berusia 50 tahun ke atas (baik yang almarhum maupun kerabatnya). Pada tingkat cucu dan cicit, tidak ada lagi yang mencantumkan NT (mengingat jarak 35 tahun antara penerbitan harian itu dan dikeluarkannnya peraturan ganti nama pada 1966). Oleh karena data diambil dari sumber tertulis, artikel ini mengesampingkan alasan pemilihan NI. Setiap orang mempunyai alasan pribadi yang tidak penting bagi orang lain meskipun menarik untuk diketahui. Dari analisis data tersurat beberapa hal mungkin merupakan alasan pemilihan NI.

\section{Nama DiRI}

Pernyataan bahwa "bahasa menunjukkan bangsa" berlaku juga bagi nama diri. Yang dimaksud dengan nama diri mencakup antara lain nama orang (misalnya Reagan, Homère, Johan), nama hewan (misalnya Belang, Putih, Bruno), nama tempat (misalnya Roma, Malaysia, Bekasi, Ancol), nama waktu (misalnya Senin, Januari, pagi, Zaman Batu, Idul Fitri), nama lembaga (misalnya Toyota, DPR, UI, PPP), dan nama karya (misalnya Layar Terkembang, Indonesia Raya, Monalisa). Dalam tulisan ini, nama diri yang dibahas adalah nama orang yang digunakan secara resmi, bukan nama panggilan akrab. Istilah yang mengacu pada nama diri orang adalah anthroponymes ${ }^{1}$ [diindonesiakan menjadi antroponim] (Molino 1982: 6).

Setiap masyarakat memiliki kekhasan antroponim seperti beberapa contoh berikut.

- nama etnik Batak: Nasution, Harahap, Hutagalung, Napitupulu, Situmorang.

- nama etnik Jawa Tengah: Retno, Setyawati, Wijanarko, Djoko.

'Antroponimi adalah cabang onomastika yang menyelidiki nama orang (Kridalaksana 1993: 5). Untuk selanjutnya dalam tulisan ini, antroponim digunakan sebagai istilah yang mengacu pada nama orang karena istilah namu diri mencakup berbagai nama. 
- nama etnik Sunda: Suparna, Djaka, Neneng, Eep Saefullah, Aang Kunaefi.

- nama etnik Jerman: Kluge, Strauss.

- nama etnik Belanda: Ernest van Zoest, Hofman.

- nama etnik Jepang: Nakamura, Kensuke, Yumiko.

- nama etnik Korea: Choi Yun So, Kim Dae Jung.

- nama etnik Prancis: Yves, Guy, Beauvilain, Le Gall, François.

\section{FUnGSI ANTROPONIM}

Benveniste (dikutip oleh Bromberger 1982: 105) menyatakan bahwa antroponim merupakan tanda konvensional, dalam hal pengidentifikasian sosial, yang merujuk secara tetap pada satu individu. Namun, pada kenyataaannya, dalam berbagai masyarakat, sebuah antroponim tidak selalu hanya merujuk pada satu orang.

Pada kajian mengenai antroponim Prancis kuno, antara lain memperlihatkan bahwa pada 1760 terdapat 128 kepala keluarga di HauteProvence (Prancis) memiliki 29 nama keluarga (patronim). Ada empat nama kecil yang dimiliki oleh dua pertiga dari jumlah tersebut.

Di samping itu, kajian memperlihatkan bahwa pada masyarakat tertentu ada pemberian nama berbeda pada tahap kehidupan tertentu. Misalnya, pada masyarakat Guidar, di Kamerun Utara, setiap orang menerima dua nama semasa hidupnya, yakni pertama, ketika ia lahir ia mendapat nama yang menunjukkan anak ke berapa; kedua, empat bulan kemudian, ia baru mendapat nama yang bersifat pribadi. Nama pertama sama bagi semua orang Guidar yaitu Tizi bagi anak sulung (sistem ini juga terdapat pada masyarakat Bali). Perbedaan nama antara anak lakilaki dan perempuan baru terlihat pada anak ke-4. Anak ke-5, baik lakilaki maupun perempuan mendapat nama Madi, anak ke-6 Todou.

Pada masyarakat lain, seseorang dapat memperoleh nama berbeda pada setiap tahap kehidupannya. Tentu saja, hal itu dapat mempersulit sistem perujukan dan administrasi yang berkaitan dengan nama menjadi lebih rumit. Dengan demikian, sebenarnya secara umum dapat dikatakan bahwa sistem antroponim tidak jauh berbeda dengan penomoran. Kenyataan ini menggugurkan pernyataan Benveniste karena sebuah nama tidak selalu secara tetap hanya merujuk pada satu individu serta dapat berubah. Bromberger (1982: 106) menyimpulkan dua hal; pertama, ada antroponim yang memiliki ciri semantis yang sama dengan kategori nomina. Tizi dapat dianalisis atas beberapa komponen makna, yaitu 'anak' +'sulung dari pihak ibu' (tidak harus dari pihak ayah); sama seperti analisis semantis nomina manusia, yaitu 'makhluk hidup', 'berakal budi'. Kedua, seperti terlihat pada ilustrasi, sistem tersebut mengandung dua fungsi antagonis, yakni fungsi klasifikasi yang merujuk pada ciri yang sama dan fungsi identifikasi personal. Makin mudah antroponim diklasifikasi makin kecil fungsi identifikasinya; makin sulit diklasifikasi makin besar fungsi identifikasinya. 
MAKNA DAN SIMBOL

Kemaknawian nama sering menjadi pertimbangan utama. Sebagai ilustrasi dapat diambil beberapa contoh nama dari etnik Jawa Tengah. Sama halnya dengan masyarakat Tionghoa, nama dapat diambil dari benda atau hal dalam kehidupan sehari-hari. Nomina dan adjektiva berikut diambil dari Kamus Basa Jazua (2000): bambang bermakna 'pemuda putra seorang satria pertapa', mulat bermakna 'intan', pitaya bermakna 'kukuh; 'sentosa'; 'dapat diandalkan', ratih bermakna 'bulan', raditya bermakna 'matahari; sunu bermakna 'cahaya', dan supangat bermakna 'doa nabi'.

Selain mengandung makna, nama merupakan simbol dengan berbagai latar belakang; misalnya untuk mengenang ibunya, seseorang memberi nama anaknya sama dengan nama ibu tersebut; kecantikan seorang anak diharapkan setara dengan bunga dahlia sehingga nama itu pun diberikan kepadanya; keperkasaan seorang putra diharapkan setara dengan guruh, guntur atau tokoh pewayangan Bima sehingga ia pun menyandang nama tersebut; orang tua menginginkan putranya terkenal seperti seorang presiden, maka diberinyalah nama Washington, Soekarno; sebagai simbol cinta mereka, orang tua menyatukan suku kata dari namanya masingmasing, misalnya Andrevi adalah singkatan dari anak (dari) Eko dan Fiona, Kuntari singkatan dari Kuntjoro dan Tariwiyani.

\section{Peraturan Pemberian Nama}

Dalam masyarakat tertentu, penggunaan nama harus tunduk pada peraturan, misalnya di kalangan masyarakat Yanõmani, ada larangan pemberian nama ayah atau ibu yang sudah meninggal. Hal tersebut didasarkan pada pemikiran bahwa nama seseorang merupakan manifestasi dirinya. Dengan demikian, ada kepercayaan bahwa pemberian nama orang tua yang sudah meninggal kepada keturunannya dapat menyebabkan umur pendek. Namun, di kalangan lain, seperti masyarakat Florence pada zaman Renaissance, hal sebaliknya berlaku. Pemberian nama orang tua dilakukan secara sistematik, bukan saja sebagai simbol garis keturunan melainkan juga sebagai harapan akan terjadinya reinkarnasi (Bromberger 1982: 119).

Dalam masyarakat Tionghoa, pemilihan nama memperhatikan: (a) delapan aksara penanda waktu kelahiran (antara lain tahun, bulan, tanggal, dan jam); (b) lima unsur: logam, kayu, air, api, dan tanah; dan (c) prinsip keseimbangan antara yin dan yang yang diwujudkan melalui guratan (aksara Cina). Namun, ada tabu untuk memilih nama yang sama dengan nama hari, bulan, penyakit, wilayah, gunung, atau sungai (Patadungan, 1993: 22, 29). Hal sebaliknya terjadi pada masyarakat Jawa Tengah seperti nama Legiyem dan Wagiman yang diambil dari nama hari pasaran legi dan runge.

\section{Antroponim Etnik Tionghoa}

Bertolak dari lingkup pembauran, sebuah penelitian pernah dilakukan untuk mengkaji NT dari segi makna dan fungsinya pada masa tradisional 
serta alasan pemilihan NI. ${ }^{2}$ Di dalam karya tersebut dikatakan bahwa NT mempunyai makna dan dikaitkan dengan tiga hal, yaitu: (a) keyakinan bahwa nama dapat menentukan nasib dan bahwa nama yang tepat dapat mengubah nasib buruk yang menjadi takdir seseorang; (b) nama adalah harga diri, seseorang dapat bangga terhadap namanya yang mempunyai arti yang baik; dan (c) nama memberi pengaruh psikologis kepada penyandangnya, sifat dan emosinya dibentuk oleh makna namanya.

Penamaan bersumber pada benda atau hal dalam kehidupan, misalnya Jin Zhu adalah nomina yang bermakna 'tiang keluarga', Jing Guo adalah nomina yang bermakna 'pemegang kekuasaan di sebuah negara'. Hasil penelitian memperlihatkan bahwa pada umumnya orang Tionghoa mempertahankan nama keluarga mereka dengan penyesuaian grafis dan fonis; ada yang mempertahankan NT dengan menerapkan maknanya pada NI, beberapa tetap mencantumkan nama keluarga asli mereka-dengan alasan bahwa keturunan mereka harus mengenal nenek moyang merekadan NI lainnya sama sekali tidak terkait lagi dengan NT-nya.

\section{ANTROPONIM INDONESIA}

Seperti diketahui, masyarakat Indonesia terdiri atas berbagai etnik yang masing-masing memiliki sistem antroponimi sendiri. ${ }^{3}$ Di samping antroponim yang berciri kedaerahan, ada antroponim yang dapat dianggap berciri Indonesia, tanpa ciri etnik tertentu. Antroponim tersebut sering diambil dari kata biasa yang mengacu pada benda atau hal, misalnya indah, cahaya, mustika, intan, mutiara, hening, ratna, guruh, guntur, bayu, topan, fajar, dan surya.

Dengan menuliskan huruf pertama dengan huruf besar, kata-kata tersebut menjadi nama orang. Demikian pula halnya dengan antroponim yang merupakan kata serapan dari bahasa Arab, pada umumnya mencerminkan ciri keagamaan (Islam), misalnya Akbar, Akhyar, Amaliah, Ambar, Amir, Ardi, Arif, Aziz, Firmansyah, Fitri, Firdaus, Gani, Kafi, Kamil, Taslim, Taufik, dan Wahid. Ada pula antroponim-dari nama nabi-yang mencerminkan agama Kristen, misalnya Habil, Ester, Paulus, Yakobus, Lukas, Markus, Yohanes, dan Yosua. Kata biasa wahyu dan antroponim Yunus terdapat dalam kitab suci Al-quran dan Injil sehingga ciri keagamaan nama tersebut bergantung pada penyandangnya.

Tidak ada peraturan secara umum mengenai antroponim bagi masyarakat Indonesia. Cukup banyak orang yang memberi nama kepada anak-anak mereka sesuai dengan yang mereka inginkan, termasuk antroponim asing, seperti Yuriko, Deryl, Natalia, Nikita, Robin, Nefertiti, Ricy, Natasha, Andre, Albert, dan Marilin.

\footnotetext{
${ }^{2}$ Lihat skripsi Patadungan (1993: 21-24).

${ }^{3}$ Pada saat ini, penulis belum menemukan kajian mengenai antroponimi masyarakat Indonesia.
} 
Nama Pengganti Nama Tionghoa

Penulisan NT biasanya didahulukan daripada NI. Pada data masih terdapat NT (tanpa NI) pada isteri, saudara sekandung atau anak. Contoh:

a. Lie Jin Sien (74 tahun)

(Joseph Liman Insan)

Isteri: Ny. Jd. Lie Jin Sien (Yong Mei Lan)

Adik: Lie Siung Sien

Lie Lai Ching

b. Lim A Lin (73 tahun)

(Leman Solihin)

Anak: Lim Jin Liang

Lim Mei Lan

Usia orang yang meninggal berkisar antara 42 sampai 88 tahun. Usia tersebut memperlihatkan bahwa keturunan pertama, isteri atau saudara kandungnya seharusnya sudah terkena peraturan ganti nama, tetapi ada yang belum atau mungkin tidak mengganti namanya. Dari hasil klasifikasi NI yang disusun berdasarkan kedekatan antara NT dan NI ditemukan ada yang NT-nya masih terlihat, NT mengalami penyesuaian grafis atau fonis, sampai yang NT-nya sama sekali tidak terdeteksi pada NI.

NI yang dipilih dapat dibedakan atas tujuh kelompok berikut.

1. Nama keluarga dipertahankan sebagaimana adanya (25 nama/3,08\%). Ada nama keluarga yang dicantumkan di muka, ada yang di belakang, seperti Ng Soesilo Gunawan (Ng Sien Fa), Suherman Thio (Thio Soe Tong). Pada kelompok ini, penggunaan nama keluarga diterapkan pula pada anak dan cucu (dari anak laki-laki), seperti $\mathrm{Ng}$ Hadi Santoso Soesilo, $\mathrm{Ng}$ Hendra Soesilo (nama anak laki-laki); Ng Yulie Indrawati, Ng Vinna Indrawati (nama cucu). Terdapat juga usaha mempertahankan suku lain dengan penyesuaian grafis, seperti Tan Samsudin Anwar (Tan Seng An), Arifin Tjhai (Tjhai Kim Phin).

2. Nama keluarga dipertahankan sebagaimana adanya, menjadi suku pertama yang digabung dengan suku lain (43 nama/4,3\%). Sebagian besar NI lazim digunakan, seperti Loekito (Loe); Gozali, Gondo (Go); Tanamal, Tantra (Tan); Tjokro (Tjo); Soeganda (Soe); Narmawan (Na); Hadisurya (Ha); Sofian (So); Pangestu (Pang); Sungkono (Sung); Gandamiharja (Gan). Namun, ada pula yang kurang lazim, seperti Lokasari, Lofunta (Lo); Yapina (Yap); Chendana (Chen); Limawan (Lim); Angwar (Ang); Oenkiriwang (Oen); Lauwidjaja, Lauwita (Lauw).

3. Nama keluarga dipertahankan secara fonetis sebagai suku pertama dalam NI dengan penyesuaian grafis dan digabung dengan suku lain (91 nama) $11,23 \%)$. Contoh untuk kategori ini adalah Widjaja, Winata, Widagdo, Wiharto, Widianingsih, Widodo, Wikarta, Widjoseno, Wibowo, Wiharja (Oey); Wibawa (Whie); Hidayat (Hie); Kusnadi, Kurnia, Kusiana (Khoe); Teja, Tejamulia (The); Chandra, Tjandra (Chen, Tjan); Kosasih (Kho); 
Djohan (Jo); Anggraeni (Ang); Tanti (Tan) Tamin (Tham), Leman (Lie). Pada kelompok ini tampak bahwa suku kata wi cukup produktif dalam pembentukan NI yang lazim. Ada beberapa nama yang terasa berbeda dengan NI pada umumnya, misalnya Lohananta, Lohanda (Loa); Mercu Buwono (Tjung); Tamira (laki-laki; Tham); Liman, Lisan, Libriyani (Lie); Tandri, Tanu, Tandra (Tan, Tjhin). Kelompok ini dibedakan dari kelompok (4 berikut ini) karena suku pertama dapat dianggap sebagai tempat yang sama dengan nama keluarga.

4. Nama keluarga dipertahankan pada suku kedua atau ketiga NI dengan penyesuaian grafis $(88$ nama/10,86\%). Contoh untuk kategori ini adalah Susilo, Pranolo (Lo); Halim, Musalim, Salim (Lim, Liem); Muliana, Rusli, Mursali, Muslina, Ali, Mulia, Soelistio, Darmali (Lee, Lie); Hartanti, Hartanto, Sutanto, Intan, Hartani, Kristanto (Tan); Prasetio, Susantio (Thio); Sugimin (Gim); Sukowidono (Wie); Otong (Ong); Supandi (Phan); Wigono (Go); Nawangwulan (Wang) Suyapto (Yap); Supangat (Pang). Terdapat nama yang kurang lazim seperti Sulim (Lim); Aly, Taruli (Lie).

5. Dua suku NT dipertahankan pada NI dengan penyesuaian grafis (40 nama) $4,93 \%)$. Salah satu suku dapat merupakan nama keluarga, seperti Sotiniwati (Lie So Tin), Suwandi Kosim (Kho Chuan Suan), Asnawi Halim (Lim Thian Wie). Ditemukan satu nama yang mempertahankan ketiga suku NT-nya yakni Setyo Setiawan (Thio She Wen), Meilina Hardjali (Lie Mei Ling). Ada nama yang gabungannya kurang lazim, seperti Firmansyah Aluroi (Liauw Yuk Tjong); Pikman Wibisono (Oei Wie Pik); Tanin Djuhari (Tan Tek Djoe).

6. Salah satu NT (bukan nama keluarga) dipertahankan (163 nama/20,12\%). Ada nama yang memang sesuai dengan ejaan NI seperti Sukidjan (Tjo Tiang Djan), Landriyati (Tjo Giok Lan), Iping Jaya (Kang Siu Ping). Ada nama yang ditulis dengan penyesuaian grafis, misalnya Yohanes Warsono (Tjan Kiem Hwa), Wirya Sentoso (Gim Wei I), Suhita Tandra (Tjhin Men Sui), Leonard Sailan (Lim Tjing Say).

7. NT tidak terlihat lagi dalam NI (349 nama/43,08\%). Nama yang dipilih pada umumnya NI yang lazim, yang diambil dari kitab suci atau nama yang berciri Barat. Contoh:

a. Hendrik Irawan (Lay Foek Nam), Suryadi Sunarso (Tjoa Bun Seng), Diany Agustin (Tjoa Kiok Nio), Asam Basrie (Hiu Nen Kiong), Dwiratna Suhardjo (Oen Tjuk Yoen). Harum Budiningsih (Oey Kwie Hiang).

b. Yohanes Hidayat (Lie King Heng), Fransisca (Pang Siang Nio), Thomas Budiman (Chuang Sin Fat), Henoch Setiawan (Lauw Tjoei Hin).

c. Claudia Christina (Tan Moei Tjin ), Brian Herabadi (The Eng Goan), Hendrik Irawan (Lay Foek nam).Jenny Andelma (Thian Khai Shien).

Ada beberapa nama yang dirasakan kurang lazim, seperti Budi Sazvahanto (Thian Jie Jim), Thomas Nagazaki (Liong Tjoen Hian), Freddy Baguna (Ong Boen Hong), Petrus Otto Toindo (Ang Sioe Leng). Sebaliknya, ditemukan nama keluarga terkenal, seperti Melani Iskandar Dinata (Tan 
Beng Giok), G. Th. Mangundap (Thio Giok Tjioe), George Wenas (Jan Khik Kay). Memang terbuka kemungkinan bahwa sebuah keluarga Indonesia memberikan nama keluarganya untuk orang keturunan Tionghoa.

Selain ketujuh pola tersebut, ditemukan dua kasus yang cukup menarik berikut ini.

(1)NI ayah: Tjahyadi Mulyawan (Tjia Tjie Kian), sedangkan anakanaknya menyandang nama yang sama di belakang nama kecil mereka, yaitu Tjandra. Padahal, nama NT mereka pasti mengikuti marga ayah mereka, tetapi pada NI mereka tidak memakai salah satu dari NI ayah mereka. Dari segi ejaan (perhatikan huruf $\mathrm{Y}$ dan J), ada kesimpangsiuran pada nama Tjahyadi Mulyawan yang seharusnya Tjahjadi Muljawan atau Tyahyadi Mulyawan.

(2)NI ayah: Mulia Hadiwinata (Oey Wie Say). Enam orang anaknya (dari 9 orang) memakai nama Hadiwinata di belakang nama kecil mereka, seperti Yos Hadiwinata, Erick Hadiwinata; sedangkan yang 3 orang lainnya menyandang nama kedua yang berbeda-beda, yaitu: Bun Winarto, I Made S.Wiguna, dan Irena Winata. Pada tiga nama yang terakhir ini marga NT Oey dipertahankan pada suku pertama dengan penyesuaian grafis.

Tampak bahwa jumlah terbesar pola penggantian NT terdapat pada kelompok terakhir. Cukup banyak WNI keturunan Tionghoa yang meninggalkan semua identitas namanya secara grafis. Ternyata, banyak suku kata Indonesia yang secara fonis bisa cocok dengan suku kata nama Tionghoa. Meskipun demikian, masih ada NI yang kurang lazim. Penambahan-wati (yang dianggap sebagai ciri keindonesiaan) dilakukan tanpa memperhatikan keserasian, seperti pada Hildawati, Pingkowati, Sotiniwati, Mariawati, Luciawati, Ellywati.

\section{Penutup}

Seperti dapat dibaca pada SK Presidium Kabinet RI, peraturan ganti nama tidak memberi batasan secara rinci dan tidak mencantumkan sanksi. Sanksi yang mungkin dihadapi dapat berupa sanksi psikologis, mengingat WNI keturunan Tionghoa sering menjadi obyek diskriminasi.

Dari NI yang demikian beraneka ragam, terlihat betapa luasnya kebebasan hak pilih dan hak cipta yang diberikan pemerintah Indonesia. Di pihak lain, makin besar pula fungsi deiktis antroponim di Indonesia. Sekarang, nama Djoko atau Wenas tidak lagi hanya pada seorang yang berasal dari etnik Jawa atau Manado, tetapi dapat juga pada WNI keturunan Tionghoa; Firmansyah tidak lagi harus mengacu pada seseorang yang beragam Islam karena dapat saja merupakan nama seorang WNI keturunan Tionghoa yang beragama lain. Sehubungan dengan itu, tercapailah tujuan asimilasi seperti tercantum pada klausul Menimbang angka 2 dalam SK Presidium Kabinet tentang peraturan ganti nama tersebut. 
Dat A A A Un

Bronberger, Christian (1982), "Pour une analyse anthropologique des noms te personnes," Inogigt's No 66, Juni.

SWhiro, lean (1982), "Le nom propre dans la langue," Langages. No. 66, Juni.

Patadungan, Chrstme Naomi D. (1993). "Makna dan Fungsi Nama Tionghoa: Cuatu Tinjuan Umum mengenai Tradisi Penggunaan Nama di Jakarta dan Sekitarnya." Skrijo Sarjana, Program Studi Cina, Fakultas Sastra Universitas Indonesia.

"Ylyti (2002), "Nama Lahir, Nama Komersial, Apalah Arti Sebuah Nama." Siom Pombanm, 2 luh 2002 . 
LAMPIRAN

\section{KEPUTUSAN PRESIDIUM KABINET \\ No.127/U/Kep.12/1966}

\section{KETUA PRESIDIUM KABINET}

Menimbang : 1. Bahwa dalam rangka nation dan character building Indonesia; proses asimilasi warga negara Indonesia "keturunan asing" kedalam tubuh bangsa Indonesia harus dipertjepat;

2. Bahwa penggantian nama dari orang Indonesia keturunan asing dengan nama jang sesuai dengan nama Indonesia "asli" akan dapat mendorong usaha asimilasi ini;

3. Bahwa oleh karena itu bagi warga negara Indonesia jang masih memakai nama Tjina, jang ingin mengubah namanja jang sesuai dengan nama Indonesia asli perlu diberikan fasilitas jang seluas-luasnya dengan diadakan prosedur jang chusus;

Mengingat : Undang-Undang No. 4 tahun 1961.

\section{MEMUTUSKAN}

Menetapkan : Peraturan ganti nama bagi warga negara Indonesia jang memakai nama Tjina sbb:

\section{BAB I \\ KETENTUAN UMUM \\ Pasal 1}

(1) Warga negara Indonesia jang masih memakai nama2 perseorangan dan nama keluarga Tjina jang ingin mengganti namanja dengan nama jang sesuai dengan nama jang lazim dipergunakan oleh masjarakat Indonesia, dapat menjatakan keinginannja setjara tertulis kepada Kepala Daerah Tingkat II atau pedjabat jang ditundjuknja;

(2) Nama2 jang dipilih tidak boleh melanggar adat sesuatu daerah atau tidak boleh dianggap sebagai sesuatu gelar, dan tidak boleh melanggar tatakesusilaan;

(3) Kepala Daerah atau pedjabat jang ditundjuknja atas nama Menteri Kehakiman memberikan tanda menerima atas surat pernjataan ganti nama jang dimaksud;

(4) Sedjak jang bersangkutan menerima surat tanda penerima seperti jang tersebut dalam ajat (3) ia dapat memakai nama jang baru;

(5) Apabila dalan djangka waktu 3 bulan sedjak ia menerima surat tanda penerima jang dimaksud dalam ajat (3) diatas, tidak terdapat sanggahan atau gugatan atas pemakaian nama baru itu dari siapa pun jang disalurakan melalui Kepala Daerah Tingkat Il jang bersangkutan, maka ia dapat menggunakan nama tersebut seterusnja dan dianggap telah mendapat izin dari Menteri Kehakiman seperti yang dimaksud dalam pasal Undang-Undang No.4 tahun 1961.

\section{BAB II \\ PROSEDUR \\ Pasal 2}

(1) Untuk menampung pelaksanaan penggantian nama setjara tersebut diatas, diadakan prosedur chusus jang menjimpang dari prosedur biasa untuk djangka waktu terbatas. 
(2) Penggantian nama menurut ketentuan ini dilakukan dengna tjara mengisi surat pernjataan dalam rangkap 3 (tiga) dimana harus ditjantumkan nama lengkap lama, tanggal dan tempat lahir serta alamat disamping nama lengkap jang baru dari jang bermaksud mengganti namanja.

(3) Setiap surat Pernjataan harus disertai surat bukti kewarganegaraan R.I. jang bersangkutan.

(4) Penggantian nama dari anak dibawah umumr 18 tahun dilakukan oleh orang tua atau walinja dalam Surat Pernjataan jang sama atau Surat Pernjataan tersendiri.

(5) Surat Pernjataan diadjukan kepada Bupati/KDH atau Walikota/KDH setempat untuk didaftar, diberikan nomor daftar dan disahkan.

(6) Satu helai dikirim kepada Menteri Kehakiman R.I. di Djakarta melalui Kantor Bupati/Walikota KDH jang bersangkutan.

Satu helai disimpan dalam arsip Kantor Bupati atau Walikota KDH jang bersangkutan.

Satu helai Surat Pernjataan segera dikembalikan kepada jang bersangkutan, untuk diusahakan perubahan akte kelahiran dan, djika ada, akte perkawinanja pada Kantor Tjatatan Sipil jang bersang-kutan

(7) Surat Pernjataan jang telah didaftar diberi nomor dan disahkan oleh Bupati/ KDH atau Walikota/KDH jang bersangkutan mempunjai kekuatan hukum jang sah.

\title{
BAB III \\ LAIN-LAIN \\ Pasal 3
}

(1) Dalam melaksanakan keputusan ini para Bupati dan Walikota KDH jang bersangkutan supaja menjediakan fasilitas 2 jang seringan-ringannja kepada para pengganti nama guna memperlantjarkan prosedur.

(2) Untuk biaja administrasi tidak boleh dipungut biaja lebih dari Rp.25,- ub (dua puluh lima rupiah ub) untuk setiap pernjataan

(3) Hal2 jang belum diatur dalam keputusan ini akan diatur kemudian oleh Menteri Dalam Negeri.

(4) Keputusan ini mulai berlaku tanggal 1 Djanuari 1967 dan berachir pada tanggal 1 Maret 1968.

\author{
Ditetapkan di : D ja ka r ta. \\ Pada tanggal : 27 Desember 1966. \\ PRESIDIUM KABINET AMPERA \\ Ket u a, \\ ttd. \\ SOEHARTO \\ DJENDERAL T.N.I.
}

(Sumber: Dikutip dari dokumen Departemen Luar Negeri Republik Indonesia.) 